GRIFFITH \& SIMON, BOOKSELLERS \& STATIONNRS, No. 384 N. Second St., Philada.

$$
92 B R \frac{500}{0}
$$

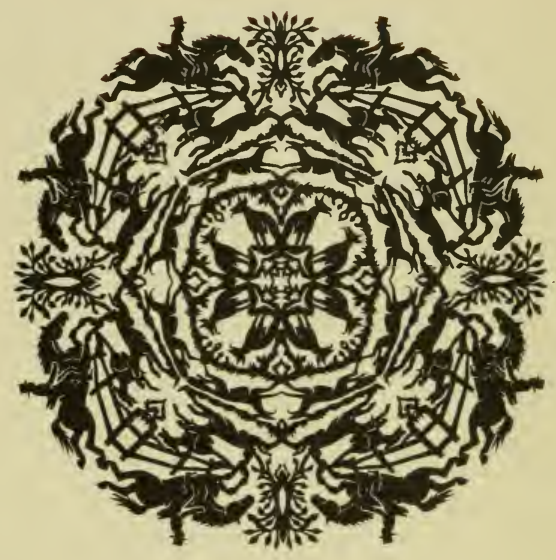

JOHN A.SEAVERNS 
TUFTS UNIVERSITY LIBRARIES

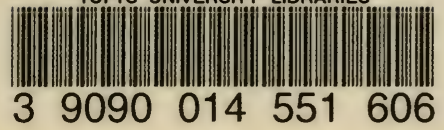

Lebeand, d.1832.

The principles and the art of

Seaverns

SF

309

L3313

1833 



\title{
THE PRINCIPLES
}

\author{
OF THE
}

\section{ART OF MODERN HORSEMANSHIP,}

\author{
FOR
}

\section{LADIES AND GENTLEMEN;}

IN WHICH

All late Inprovements are applied to Practice.

B Y M. LEBEAUD.

$\rightarrow \gg 0$ e्ष

TRANSLATED FROM THE FRENCH,

By DANIEL J. DESMOND, Esquire.

\section{PHILA DEL PHIA:}

E. L. CAREY \& A. HART-CHESNUT STREET. 
Entered, August, 1833, according to Act of Congress,

By E. L. Carey \& A. Hart.

In the Clerk's Office of the District Court, of the Eastern District of Pennsylvania. 


\section{PREF ACE.}

$\leadsto \gg \bullet \ominus \bullet \ll-$

A Desire to promote the study of a healthful and graceful exercise, and a wish to advance the interests of a friendless stranger, are the motives that have induced me to present to the public the Manual of the Art of Equitation, by $M$. Lebeaud. The coincidence of utility and benevolence, has rendered the task of translation interesting and grateful. The want of such a manual is very sensibly felt by all who are desirous of uniting a knowledge of the principles to the practice of the art.

However attentive and intelligent an instructor may be, many things will remain without explanation, and many be performed without knowing the principles on which they are done. To supply this deficiency the following work is offered. It is selected from 
the collection of valuable manuals which have within a few years issued from the French press. It contains instructions to train a horse to all the regular and artificial gaits that are necessary to develope his qualities and strength, and to secure the safety, and display the skill and grace, of the rider. But it is not pretended that this manual will render a person a consummate rider. It is, indeed, asserted by the author, M. Lebeaud, that it is impossible to become an accomplished horseman, without uniting practical lessons to the study of the art of equitation. To all who are ambitious to become skilled in this art, or who are led by impaired health, to resort to it for healthful exercise, the practical lessons of $\boldsymbol{F}$. G. Bertola will be fuund an admirable auxiliary, to impress, illustrate, and confirm, the principles and instructions of this manual. It cannot escape observation, that a taste for riding on horseback is manifesting itself among the ladies and gentlemen of Philadelphia. It must be acknowiedged that few of our riders are skilful or graceful, and scarcely any of our riding horses are trained to the regular and artificial gaits of the manége. This little work is now pre- 
sented to the public to give a proper direction to a growing taste, and to obtain a portion of its patronage for a skilful horseman and a friendless foreigner.

DANIEL J DESMOND.

August 24th, 1833.

$\rightarrow+00$

NOTE BY THE TRANSLATOR.

When a gentleman accompanies a lady on horseback, he should take the left side of her horse. The custom of taking the right side, is derived from the English mode of riding. The law of England directs the left hand of the road to be taken; the gentleman therefore takes the right, to protect the lady from vehicles, \&c., which pass on her left. Here the law directs the right hand of the road to be taken, consequently the gentleman should take the left side of the lady's horse. It seems to be best adapted to afford efficient 
assistance whatever may occur. The right hand of the gentleman is perfectly free, and may be used either to stop the horse, or rescue the lady from danger. He can on this side aid her in disentangling her dress, disengaging her foot from the stirrup, adjusting her reins, and lifting her off of her seat, without exposing her to the accidents which might occur to him if he attempted to give her assistance from the other side. It is not so easy to afford assistance to the lady with the left hand, nor is it so easy for the rider, to command his own horse with the right hand. 


\section{O N T E N T S. $\rightarrow \gg 99 \bullet$}

\section{CHAPTER I.}

Of the Mrans used to Break Horses.

Of the Longe, Cavesson and Pillars,

Of the Bridle and Bit, and of their different effects, 15 Of the Choice of the Bridle, according to the Quality of the mouth,

Of the manner of Bridling and unbridling,

Of the Saddle, and its different parts,

23

Manner of Saddling and unsaddling,

Of Helps and Chastisements,

\section{CHAPTER II.}

Elementary Principles of the Manége.

Manner of Mounting and Sitting on a Horse, 41

Work on a walk, or on a trot, 47

Of the trot upon the Circle, $\quad 51$

Of Exercise on a Gallop, $\quad 52$

Of the shoulder inward, and of the croup to the wall,

Of stops, half stops, of falling back, and of the changes of hand,

\section{APPENDIX.}

\section{Directions for the Ladies,}

Of Mounting,

73

Of Dismounting,

Vocabulary,

81 



\section{THE}

\section{AR'T OF HORSEMANSHIP.}

$\rightarrow$ अ

\section{CHAPTER I.}

OF THE MEANS USED TO BREAK HORSES.

Of the Longe, Cavesson and Pillars.

The longe, is a long cord of the thickness of the little finger, at the end of which is a ring attached to a leather, which is passed into the ring of the middle of the cavesson. It is very convenient to supple young horses, that are to be made to trot upon a circle; also for those that are restive, unsteady, or retain their strength through malice; and it serves for many other uses.

There are two kinds of cavesson; one of leather, and the other of iron. 'The first is a sort of nose-band, which encompasses the nose of the horse with two bands, which go 
up the sides to be attached to a head-stall back of the ears, and a frontal upon the forepart. The cavesson of iron differs from the other only, in the nose-band being formed of iron on the front. This cavesson is furnished with three rings of iron, one on each side, and the third in the middle upon the nose.

The effects of the cavesson differ essentially from those of the bridle; the bridle acts directly on the lower jaw of the horse, and the cavesson entirely on the nose. Now, this part being much less sensible than the former, the cavesson gives the means of moulding an untrained horse to all the movements that it is desirable to make him exe. cute, without fatiguing his mouth; it prepares him for the effects of the bridle, and governs the mouth of horses that are trusted to beginners.

The pillars are two round posts, six feet high, placed in the middle of a manége, five feet fron each other, terminated with a headtop pierced with holes, and furnished with rings at the top. The horse that is to be trained to piaffing, or to certain lofty airs, or that is to be made vigorous, is tied between these pillars by the side rings of the cavesson. 
But this mode, applauded by many able horsemen, and censured by others, demands on the part of him who gives the lesson, much tact, experience, and a great habit of using the chambriere judiciously; for without these qualities, the lesson of the pillars would serve to injure the intelligence of the horse, or to confirm him in faults that ought to be corrected.

Of the Bridle and Bit, and of their different effects.

The bridle should be, in the hand of an able horseman, not an instrument of constraint, but one of assistance, and a means of warning. It is composed of four principal parts, which are : the bit, the branches, the curb, and the reins. French bridles have, besides, a nose-band, a throat-band, a frontal, and a head-stall. English bridles have four reins, instead of two, a snaffle, independently of the bit, and no nose-band.

The bit, or mouth-piece, is a bit of iron, sometimes straight, crooked or jointed, which is put into the mouth of the horse. This piece is called the canon; the two extremities, 
to which the branches are attached, the ends of the mouth-piece, and the part which rests directly on the horse's nether jaw, the heel.

After having much diversified the form of the bit, three of the principal ones are now generally adopted, to wit: the simple bit, broken in the middle, which renders it the mildest mouth piece ; the bit "a trompé," or of a single piece lightly bent to an obtuse angle, which is the severest of all ; the pigeon throat bit, " a gorge de pigeon," or free tongue bit, is sufficiently bent, so that the tongue can lodge in the empty space in the middle. This last is the most generally used ; the bit with the canon, simple or broken, is more suitable for young horses, that are not yet much accustomed to feel the iron in their mouths.

"Nothing is more important to a rider, than to know the effect of different bits upon the mouth of his horse, for it is on the manner with which this part of the bridle is regulated, that the obedience of the horse, and often the security of the rider, depends.

"This knowledge is acquired by habit; we often attribute to the insufficiency of the 
bit, that which is but the effect of the ignorance of the rider."

The branches, are two upright bars of iron, to which the canon is attached by the ends of the mouth-piece; and it is by them that the bit holds the bridle, and that the hand of the rider makes the mouth-piece act. Formerly the branches were made round, in many modes, and very complicated; now, straight branches in the English fashion, are generally adopted. There are three principal parts belonging to them; the eye, which is a hole placed at the end of the short extremity; the body or the cheek of the bit to which the ends of the mouth-piece are attached; the ring of the drill opposite to the eye. The separation of the branches, and consequently the length of the mouth-piece, should be proportioned to the conformation of the mouth of the horse.

The porte-mors, or the leather which fastens the bit and the bridle, is a little strap which proceeds from each eye and is attached to the reins.

The curb is a chain of iron composed of large and small rings of a $\mathrm{S}$, and of a hook which passes behind theback part of the mouth, and is at- 
tached to the eye of each branch. The reins are two long straps, which are attached at one end to the ring and join each other in the hand of the rider.

In the English reins the second pair is attached to the snaffle.

In recapitulating what has just been said on the four parts of the bridle, it will be perceived that it is composed : of a bit designed to rest upon the nether jaws at a finger above the hooks, in order to make the horse know the will of his rider by different degrees of pressure impressed upon this very sensible part of the mouth; of two branches which are levers or movers of this bit; of a curb which augments their action, and the latter in pressing the back of the mouth every time that the rider makes the bit felt; in fine, reins, which are the movers of all the other parts of the bridle.

The snaffle is a sort of canon, broken very small, upright, without branches, without nose-band, and without curb, and which bears rather upon the lips, than upon the nether jaw; it is serviceable for young horses that are just beginning to be trained, and that have not yet had iron in their mouths. 
The snaffle, which is now generally added to the ordinary curb, is almost indispensable, for if an accident occurs to the bridle, which renders it useless, the rider recurs immediately to the snaffle, and is not at the mercy of his horse. It offers besides the means to ease the mouth by alternately using the curb and snaffle.

Of the Ckoice of the Bridle, according to the quality of the mouth.

It is necessary, says M. de La Guérniere, from whom this article is borrowed, to adjust the bit according to the interior structure of the mouth of the horse, the branches follow. ing the proportion of the chest, and the curb following the sensibility of the back part of the mouth. The bit should bear upon the nether jaw, a finger or more from the sharp teeth of the lower jaw, for if it bore higher, it would wrinkle the lips, which would have a very bad appearance, and besides would bruise them. It is necessary, in order that the mouth-piece be well seated in its proper place, that the heel be entirely straight from the holes which hold the mouth-piece to the place 
where the bit gives liberty to the tongue, that is to say, of the length of about one inch and a half, if not, its action in the mouth would be false. It is also necessary, that the rest be made half a finger from the place where the bit gives liberty to the tongue, otherwise the nether jaw and the tongue would be wounded; that the lip of the horse be so exactly lodged that the mouth piece cannot be seen at all; in a word, that all the pieces of the bit, be well polished and well joined. The curb should bear flat, immediately below the bone of the under jaw, for higher or lower, its effect would be almost nothing.

The power of the bit should be proportioned to the size of the mouth. Where too much iron is used, that is to say, a mouth-piece too thick for a mouth but little open, it necessarily causes the lip to wrinkle; on the contrary, if it is not sufficiently strong for the slit, it enters too much forward, and it is then said that a horse drinks his bridle.

Although a good mouth is not injured by any bit, it is better to use a mild one, in order to preserve it a long time in a good state.

As to horses that have defective mouths, or that resist the bit, you must correct these 
faults by the particular form of the mouthpiece.

Mouths which cannot support the action of the bit, are called wild mouths, or too tender.

This excessive sensibility, which proceeds either from too elevated and sharp netherjaws, or from wounds caused by a bad mouthpiece, makes the horse shake the bridle at the least movement, as if to disengage himself from it, giving blows with the head, and beating in the hand.

Naturally tender mouths, require a broken bit with the end of the mouth-piece a little strong, the branches straight and long, and the curb a little slack. If this sensibility be accidental, there is no necessity to indicate the remedy.

The strong mouth is that which draws the hand, and resists the action of the bit, either because the lower jaws being round, fleshy, or too low, the bit rests more upon the tongue than upon them, or because the too great thickness of the lips and the gums covers the lower jaws. The pigeon-throat bit is the most suitable for these sorts of mouths, because the tongue is at liberty, and in order to render it more sensible, it is necessary to 
choose it a little slender, particularly near the ends of the mouth-piece.

Weak mouths that rest upon the bit with great difficulty, however mild it may be, without however beating the hand, require the same species of mouth-piece as moutlss that are too tender.

Horses which have the head fleshy, the chest broad, the lower jaws and the tongue large, bear hard upon the hand, that is to say, rest much on the bit.

It is necessary to give them a pigeon-throat mouth-piece, with little iron, the space for the tongue being proportioned to its volume; a slender curb, somewhat compact, because such horses have their under-jaws thick, and of little sensibility; a horse also often bears upon the hand from natural weakness, either from the feet, the reins, or the hips; he then seeks to sustain himself upon the bit; the conformation of the bridle cannot correct this fault.

Mouths with too great a slit, require a stronger mouth-piece, the curb for which should be placed a little low; without this last precaution, the curb would produce no effect, 
when it is wished to bring down the nose of the horse.

Horses that have long, slender, and very supple necks; those that have that part of the body, from the head to the shoulders, high, the throat rigid, the muscles of this part very thick, and the nether jaw compact, are liable to resist the bit in two different ways, which renders its action of no effect; first, they make their necks like that of the swan, throw down their heads, and rest the branches against the breast; and the second way is, they carry their heads forwards without bend. ing the front, and rest against the throat, which at the same time relaxes the curb. Horses that resist the bit on the breast, should have a very mild mouth-piece, or even a simple snaffle, and the others should have very strong branches.

Too strong a pressure on the bit, is sometimes sufficient to make a horse resist the bit, in such a case it is only necessary to destroy the cause, in order to remove the effect.

Of the manner of bridling and unbridling.

You must place yourself on the near, or 
left side of the horse, holding the bridle on the bend of the left arm; you must unbuckle the halter, to disengage the head from the nose-band. Take the head-stall of the bridle with the right hand, the bit of the bridle and the snaffle with the left hand, at the same time rest the thumb upon the left under jaw, to force the horse to open his mouth, into which immediately place the two bits, pass the head-stall above the ears immediately afterwards, commencing on the right; throw the reins upon the neck, buckle the nose-band, the throat-band, disengage the hair of the tuft, hang the curb on the hooks, and observe that all the parts of the bridle, and the mouthpiece, be placed as they should be.

To unbridle a horse, commence by unhanging the curb, and unbuckling the throat-band, and the nose band; bring back the reins to. wards the head-stall, and remove it in the same manner that you placed it; the other parts of the bridle will follow themselves.

Such are nearly all the principal precautions to be used in the choice of a bridle, but it is not sufficient to know how to adapt it to every mouth, if you have not a good hand accustomed to its effects, and to manage it; 
for the best of bridles would be almost useless in the hands of a bad horseman.

Of the Saddle, and its different parts.

A horseman ought to pay great attention to the conformation and the choice of his saddle, as it may not only wound his horse in a dangerous manner, but even cause himself great fatigue, and sharp sufferings. A saddle to be good, whatever may be its form, should fit the shape of the horse, so as not to cause rubbing, be a little stuffed but very even, in order that it may bear every where equally, and not cause any bruises. It is also necessary, in order that it may be agreeable to the rider, and that he may sit at ease, that the seat be very smooth and equal; a little hard, not higher on the front than the back, and let it have but little thickness between the thighs and the body of the horse.

The parts of which a saddle is composed are : a saddle-bow, side-bars, sides of the pummel, the pummel, the withers, the seat, the pannels, the quarters, and girth-leathers. The accessory parts are the crupper, the 
portrail or breast leather, the girths, and the stirrup straps.

The saddle-bows, are two pieces of beech wood, turned round to embrace the back of the horse. They give form to the saddle, and support all the other parts. The front bow comprises the pummel, breasts, and points; the pummel is that rounded part which surmounts the withers; the breasts are the sides of the bow, the extremities of the breasts form the points.

The back bow, is more widened and rounded than that of the front, on account of the wider form of the hips. It is surmounted in French saddles by a species of edge or border, which surrounds the reins of the rider, and which is called troussequin.

The side bars, are two little pieces of wood, three or four fingers wide, and of the length of the saddle, which make fast and tie the bows. They should bear exactly the length of the back below the spine, in order to prevent the bows bearing upon the withers and upon the reins.

The pannels are two cushions of linen, stuffed with hair, as hair of a cow or of a deer, which line the two sides of the saddle. They 
should be made of fine linen, as it does not imbibe the perspiration as much as the coarse linen; the wadding of hair, or of the hair of a deer, is most suitable.

The seat is the top of the saddle; at the commencement of this article it will be seen what qualities it ought to have; it must be remarked, that a seat too much stuffed, heats and excoriates more quickly the seat of the rider.

The quarters, are the external sides of the saddle, whatever may be the matter of which it is composed. It is necessary they should be wide and long, for too short quarters incommode the rider very much, and excoriate the ham.

The sides of the pummel, are, an edge or border, which may be remarked at each side of a French saddle, and which serve to sus. tain the thighs of the rider.

The "contre sanglons," or girth-leather, are little straps nailed to the side bars of the saddle bows, to the number of three, on each side, and which serve to attach the girths.

The girths, serve to fix, and tie the saddle upon the back of the horse. They should be 
wide, and sufficiently strong to resist every effort the horse can make.

They are generally three in number, but sometimes a surcingle is used ; this is a fourth girth, which passes over the saddle, and is attached under the belly, in order to strengthen the girths.

The portrail, or breast-leather, is a piece of leather with three angles, to each of which is a little strap, two of which serve to attach it to the sides of the saddle-bows of the front, and the third passes between the legs, to be attached to the first girth under the belly.

The breast-leather, serves to prevent the saddle from moving backwards, and from wounding the reins; it should not descend below the joint of the shoulder, so as not to constrain the movements of the horse.

The crupper, is a strap attached to the back bow, and terminated by a sort of ring, into which the stump, or trunk of the tail, is passed, in order to hold the saddle, and prevent it from moving upon the withers and shoulders. The species of cushion of which this ring is formed, is called culeron; it should be sufficiently large, so as not to wound the horse under the tail, an accident which hap- 
pens often enough, in summer particularly, to horses low in front.

The stirrup straps require no description.

A saddle which has no sides to the pummel, nor edge or border to the back bow, is called a smooth or plain saddle.

It is generally acknowledged that saddles of this form are convenient and agreeable, and now scarcely any other saddle is used; such are the English saddles; but whenever there is a necessity for putting a portmanteau behind the saddle, it is good to have a troussequin to defend the reins of the rider.

As the perspiration which the pannels of the saddle imbibe, hardens them, so as to sometimes wound the horse, it is good to line this part with calf or buckskin, for horses that perspire much.

\section{Manner of saddling, and unsaddling.}

After having lifted up the girths, the stirrup straps, and the crupper, upon the seat, you will pass the left hand under the withers, and the right under the troussequin, to raise the saddle up, and place it gently upon the back of the animal, a little behind, in order 3* 
to take the tail with the left hand to twist it about for the purpose of passing it into the crupper; taking care to disengage the hair from within the culeron, or ring of the crupper, that they may not break nor wound the horse. Returning then from the near side, you will lift up the saddle softly, to advance it towards the withers, observing always, the front bow should be three breadths of the finger from the shoulders, and that the crupper does not draw too much, in which case it must be loosened. You will then attach the breastleather in front, and finish by attaching the girths.

If you place a cloth, or schabraque upon the back of the horse, you must take care that it does not make any folds; you must observe also, that if the saddle was placed too much in front, or too much behind, it would wound the withers, or the reins, and constrain the movement of the shoulders, or the hips.

You will commence to unsaddle by detach. ing the portrail or breast leather, and the girths; you will draw the saddle "behind to withdraw the tail from within the culeron or ring of the crupper. You will lift the stirrup straps, the crupper, and the girths 
upon the seat; after having cleaned them if they are dirty, you will raise the saddle softly, drawing it towards yourself, in order to take it away; you will carry it away in the same manner that you brought it; you will then occupy yourself in washing the legs of the horse, with rubbing him with a wisp, after which you will put his covering on him, and conduct him to the stable.

\section{Of Helps and Chastisements.}

Helps are different useful signals, to warn a horse of the movements he must execute; chastisements are the means employed to correct him when he commits a fault. There are four principal sorts of helps : different movements of the hand; of the bridle; the riding whip; appeal to the tongue; various manœuvres of the thighs and legs of the rider.

The movements of the bridle or left hand are the means of warning most frequently employed, and the action which the bridle produces in the mouth of the horse, is the effect of the different movements of the hand. A good hand should be light, soft, and firm, 
qualities which depend not only on his action, but also on the seat of the rider upon the saddle; for when the body is not steady, the hand cannot be. It is necessary also, that the legs should correspond with the hand, otherwise the action of the hand would never be just; this is called, according to the terms of the art, the agreement of the hand and heels, which is the perfection of all the helps.

A light hand, is that which does not feel the rest of the bit upon the lower jaws; a soft hand, that which feels the effect of the mouth-piece a little, without giving too much rest; a firm hand is that which holds the horse strongly on a rest.

It is essential to know how to accommodate these three different movements of the hand, according to the nature of the mouth of every horse, without constraining, and without abandoning all at once the proper rest of the mouth ; that is to say, after relaxing the hand, to draw it back softly, to seek little by little the rest of the bit, and also to take up the rest strongly. You must not pass hastily from the firm to the light hand, nor from the latter to the former, because by doing so you would very soon ruin the best mouth. 
The hand should always give the first warning, and the legs should accompany its movements, for it is a general principle in all the gaits of a horse, that the head and shoulders of a horse should set out first. Now, as the horse has four principal gaits, which are, to go forwards, to draw backwards, to go to the right or to the left, so the bridle must produce four different effects, to let go the hand, withdraw it, and to turn it, to the right or left.

There are two ways of yielding the hand: the first is, to bend the hand downwards by turning the nails of the hand a little under ; the second is, to take the reins with the right hand, loosening them a little in the left hand; which makes the feeling of the bit pass from the latter to the other, and in a word, to let the right hand fall upon the neck by relaxing altogether the reins of the left hand, which is called, letting the hand fall. The action of holding the hand, or letting the hand fall, is for the purpose of pushing the horse forwards. The true time of executing this usefully, is after having marked a half stop, and when the horse bends his hips, but not whilst he is upon his shoulders. 
The action of drawing back the hand, is made by drawing it against the stomach, the nails of the hand turned a little upwards; the object of it is, to stop the horse by making a half stop, or to draw well backwards. You must, during this movement, not press too much upon the stirrips, but put at the same time your shoulders a little back, in order that the horse may stop or draw back on his hips.

The third and fourth movements are, to turn the hand to the right or to the left; the nails of the hands should, in the former case, be upwards, in order to make the right act. A horse obedient to the hand, is one that follows all its movements.

There are three ways of holding the reins; first, separated and in both hands, even in the left hand, or one longer than the other, according to the side on which the horse is to be exercised.

The separated reins are necessary for horses not yet accustomed to the effects of the left or bridle hand, or for those who resist or refuse to turn with a single hand. You must bend the left hand downwards when you draw the right hand rein to turn from this 
side, and reciprocally; otherwise the horse would not know which hand to obey.

The reins are held even, or equal, in the left hand to conduct an obedient horse in any circumstances; but in the manége the inside rein is held a little shortened, for the purpose of placing the head of the horse on the side on which he goes; for a horse that does not fold, has a bad appearance in a manége ; it is more difficult to bend a horse to the right than to the left, as much because the greatest number of horses are more stiff to the right hand, than by relation to the disposition of the reins in the left or bridle hand; there are but few persons who know very well how to use the right rein.

You must hold your hand a little higher for horses that carry low, in order to lift up their heads; it should be lower and drawn near the stomach, for those that carry their noses in the wind, in order to bring the nose and the head down. When you carry your hand forwards, the curb is relaxed, and the effect of the bit diminished; the contrary happens when you draw it near your stomach ; this is good for horses who draw on the hand. Every rider who does not perfectly know the 
different effects of the reins of a bridle, will work without rules, and without principles.

The appeal to the tongue, or speaking to the horse, which every person knows awakens his attention, animates him, and renders him attentive to the other helps, and to the chastisements which follow them, if he does not answer to them, but you must not speak too strongly nor too frequently. It is a shocking impoliteness to speak to a horse in the presence of a person on horseback, when you are yourself on foot.

The riding whip is, according to the occurrence, a help or a chastisement; it is a help when you make it whistle in your hand to animate the horse, when you make him lightly feel the point of it on the shoulder to make him lift up; upon the crouper to awaken the movements of this part, etc. In the manége, the whip is carried on the side opposite to that on which you conduct your horse, because you should never use it but to animate the outside parts. You must also hold it so as not to touch the horse without necessity. The rider draws five particular helps from the movement of the legs : the pressure of the thighs, of the knees, and of the hams, 
of the calves, and the delicate pricking of the spur, and the action of pressing on the stirrups.

The help of the thighs and the back part of the knees, is made by pressing them on both sides at once, for the purpose of urging the horse forwards, or only on one side to warn him that he yields too much on this side. This help when used a little vigorously, is often more efficacious than the spur, for ticklish horses that hold back from pure malice; that of the calf of the legs, which is produced by drawing them near the belly, warns the horse that he has not answered to the first warning, and that the spur is not far off.

The delicate pricking of the spur, which ought to touch the hair lightly, and not to prick the hide, is more expressive than all the helps, and if the horse does not answer to it, you must press the spurs vigorously. To conclude, the pressing on the stirrups, although the mildest of all the helps, is sufficient for very tender and well trained horses. You must sometimes press at once upon the two, sometimes upon the one inside or outside 
according to the species of warning that you wish to give.

When the horse does not answer to any help, whether it be through malice, or on account of a want of sensibility, you should correct him instantly, and proportion the vigour of his chastisement to the gravity of his fault ; but above all, according to the knowledge you have of his disposition; for if he is a horse that is sensible to the least punishment, you would dishearten and injure him if you chastised him beyond measure.

The chastisements most in use are, the chambriere, the riding whip, and the spur.

The chambriere is a long strap of leather, attached to the end of a handle, which should be four feet long. It is used to give the first lessons to young horses, that are being trained to learn them to piaff in the pillars; to give heart to a lazy horse; to conquer a restive horse, or an unsteady one, that defends himself against the spurs, \&c. ; the chambriere is preferable to the whip in these different cases, because, being sometimes obliged to use it vig. orously, you need have no fear of contusions, or bruises, which the cord of a whip would cause. To push the horse forwards, you strike 
him with the riding whip upon the belly and buttocks, and to prevent him from kicking up his hind feet, you strike him on the shoulder.

The spur is composed of three principal pieces; the body or the branches, the neck and the rowel : the neck should be a little long, in order that the rider may not be obliged to press the heel too much to reach the belly of his horse, and the rowel ought to have five or six very sharp points.

Spurs can be used with great success to render a horse sensible and acquainted with the helps : they should be used with discernment : you must use them vigorously when there is occasion, but never without necessity. To use the spur properly, you must draw the calf of the legs, and rest the rowel strongly against the belly, about four breadths of the finger behind the girths; for if you attack the flanks, this part being much too tender, the horse would kick and stop short, instead of advancing. Riders who apply the spurs with a single blow, astonish and surprise the horse, who does not then answer as well, as when he anticipates it by the sensible approach of the calf of the leg. The delicate pricking of the spur, sometimes becomes a 
sufficient punishment for extremely sensible horses.

It is in the use of a wise combination of helps and chastisements, that almost the whole art of a good horseman consists ; still you must use these different means in time, and judiciously.

You must assist and chastise your horse, without making any great movements. Nothing is more ridiculous than bad horsemen who act on their horses in a hundred ways, and perspire, as it is said vulgarly, blood and water, without its redounding to their honour; whilst a true rider will do every thing he wishes with his horse, without having (if I may be allowed to say so), the appearance of being occupied. 


\section{CHAPTER II.}

ELEMENTARY PRINCIPLES OF THE ART OF THE MANÉGE.

Manner of Mounting, and Sitting on a horse.

BEFORE mounting your horse, you should glance your eye over his whole equipment; this examination is the affair of an instant when you have acquired a habit of making it, and may prevent many accidents. You will at first examine if the throat-band is not too tight, or the nose-band too loose ; if the bit is not too high, which will wrinkle the lips, or too low which will make it bear too much on the hooks; if the curb bears well on the flat side; if the saddle is not too far forward, or too far behind; if the girths are not too loose, which will make the saddle turn under the belly of the horse, or too tight, which will make them break, or suffocate the horse; if the breast-leather is well placed, the crupper

$$
\text { 4*, }
$$


but not too much, sufficiently long; if the stir. rup strapsare not too long, or too short, \&c.

Having made this examination, you must approach the left shoulder of the horse, saying to him, ho, to warn him for fear of startling him: you will hold the whip in the left hand, its point down; you will pass the reins into this hand, after having adjusted them with the right hand; in this manner you will take a handful of hair at eight or ten inches above the wither. Taking then the stirrup-strap with the right hand, you will raise your leg without bending your body, to place your foot into the stirrup, taking care not to touch the belly of the horse, after having taken a second point of rest, by laying hold of the back bow of the saddle with the right hand, as far forward as it is possible, you will raise yourself to the height of the saddle, without bending the body; you will extend the right leg, which you will pass above the croup, after having let go the back bow, advancing your hips and examining your reins thoroughly, you will fall into the saddle without jolting, and with the proper posture of your body. These various movements should be executed with grace, with ease, 
without precipitation, and without touching the horse, either with the point of the left foot, or the leg of the right.

After having let go the mane, and seated yourself on the saddle, you must pass the whip in the right hand above the chest of the horse; take the end of the reins with the same hand, to equalize them, and to adjust them in the left, holding them separated by the little finger, and letting the button fall upon the right shoulder of the horse; fold the end of your fingers in the hollow of your hand, the nails above, and extend the thumb upon the reins to make them secure; in fine, to strengthen you on the seat, your waist and buttocks removed from the back bow, the reins folded and firm, without stiffness.

A beautiful posture, giving the rider no less advantage to govern his horse, than grace, is the first quality which a scholar ought to endeavour to acquire.

Grace does not consist in sitting on a horse immoveable, as fixed and as stiff as a piquet, nor in affecting a studied attitude, but to know well how to yield, or to resist, in proper time, the different movements of the horse : to pre. serve the equilibrium and perpendicular posi- 
tion, without which you cannot be master of yourself or of your horse; in a word, to preserve in all his movements the temper, freedom, and ease, which are natural to him.

The body of a horseman may be divided into three parts ; two of which, the high part and low part, should remain moveable, and the third part immoveable. The high part, comprehends the head and the body to the waist. 'The head should be straight and high, without affectation, free between the shoulders, and looking between the ears of the horse, the breast widened, the shoulders free, parailel, well covered, and a little thrown behind.

The arms should fall perpendicularly against the body, without sticking to it; the parts of the arm between the elbow and the wrists extended forward, without stiffness. The left, or bridle hand, governs the fore part of the horse, it should be placed at the height of the naval, at four or five breadths of a finger from the belly; let the lines which tie the fingers to the hand, be perpendicular to the bow, the right ought to be placed at the height of the left hand, and near it ; the point of the whip should be always turned down, falling between 
the shoulders of the horse, and the thigh of the rider.

The middle part of the body is immoveable, and naturally forms the point of rest of the rider. For this rest to be perfect you must advance the waist and the hips, hold the thighs extended, and turned inwards, draw back and close the knees, and sit upon the rump.

On the position of the lower part of the body, depends the perpendicular position which is so necessary to a horseman, these parts serve besides to govern the body, and the back part of the horse.

The thighs, and the hams must be turned inwards, in order that the flat part of the thigh may be (so to speak,) stuck along the length of the quarters. The true position of the legs, is to fall perpendicularly, from the knee down, and to be at once free and firm, for without this security, the legs will be tossed against the belly of the horse, and will keep him in a continual state of restlessness; if they are too far from the belly, they will take away the facility of aiding or chastising the horse properly; if too far advanced, they will correspond with the breast, instead of the belly; if ton far behind, they 
will correspond with the flanks; in a word, if they are held too short, they would raise you from the saddle, when you would press upon the stirrups.

The point of the foot ought to be turned a little inwards, a little lower than the heel, without being too much so, and jut out of the stirrup an inch or two at the most; all the movements of the different parts of the body should be supple, united, and little extended. Put your foot to the ground, according to the same principle, which you observed in mounting your horse, and immediately detach the curb.

The first lessons of equitation should be directed to the instructing the scholar to learn to hold himself well upon the saddle, and to maintain himself there, in all the movements which his horse can execute. Nothing is more efficacious to attain that, than the lesson of the trot, because that gait being the one that shakes the rider most, the others are but play after it.

After having acquired in school this perpendicular position, and this firmness, of which we have just spoken, you must exercise your 
self upon young horses full of ardour, and of vivacity, in order to be sure of yourself.

Work on a walk, or on a trot.

After having exercised yourself many times, mounting and dismounting, without stirrups or spurs, the beginner will place himself upon the saddle, observing in the position of the different parts of his body, the precepts developed in the preceding article, and will put his horse on a walk upon the right hand track.

For that purpose, he will let the left hand fall a little, making the help of the legs felt at the same time; movements which should be accompanied with a light blow of the whip upon the right shoulder, without otherwise deranging the hand.

Whilst the horse walks, you will use the helps of the legs with exactness, that is to say, very equally, in order to maintain him in a right line, and to sustain his pace; you will take equal care not to derange any of the parts of the body from their proper situation, because it would harden the horse in error, and would force him to break from the line. Having arrived at the end of this line, which 
is ordinarily marked by an angle of the wall, or de haie, the rider will assist the horse, by taking this angle well, to turn regularly, for that purpose he will carry the hand to the left, and will turn it afterwards in a manner that the thumb may be directed on this side, and the little finger.towards the right, the nails a little above, in order to make the right rein act more or less according to the sensibility of the lower jaws, and as soon as the horse will have obeyed, you will keep him as before in a right line. That this movement may be executed regularly, it is necessary that the head, the shoulders, and the hips pass successively in the angle, and so make at the same time the help of the legs felt, but particularly of the right, in order that the back part of the horse may not be slow.

After having again travelled over a certain distance in a right line, you will execute one as the first time, to the right, to put yourself in a parallel line to the first, and at the end of this line you will dispose yourself to turn in the inverse sense to the two former terms, that is to say, by turning the nails a little downwards, and by pressing the left leg a little more. 
In this manner you will place yourself on the left track, and you will turn the corners in the same sense, till you execute a new change of the track or hand. It is well to observe, that when the horse turns to the right, or to the left, the shoulder of the rider on the opposite side, remains naturally back, which gives a bad appearance, and removes a part of his perpendicularity; this he must avoid, by advancing imperceptibly this part, until it is replaced in the right line.

When you have been sufficiently exercised on a walk, and when you have acquired the necessary perpendicularity, you will pass to the lesson of the trot, which is the only thing that can give the degree of suppleness and perpendicularity, without which you cannot be a perfect horseman.

To start on a trot, you must bring up your horse, yield the hand, and take it up quickly ; draw your legs near, a little lively, and very equally.

In going, you will yield the hand very softly, until it be well replaced; above all, it is necessary to pay attention not to resist at the departure of the horse, nor during the return. 
In proceeding thus in the trot, you must recollect the position which the three parts of the body should have; to turn the thighs upon the flat part, and to leave them like the legs, to their own weight; it is only by this means, that the movements of the rider will harmonise perfectly with those of his horse.

You follow the same tracks on the trot, as on the walk; the turnings and changings of the hand operate in the same manner, with this single difference, that the help of the legs ought to be a little more vigorous, in order that the trot may not slacken. You must never terminate the return of the trot without having restored the horse to a walk.

With this view, to pass from the first gait to the second, you will execute a half stop, by drawing back the left hand a little, and pressing the legs lightly, in order that the horse may not stop, and also that he will have obeyed, you will replace your legs and hands. You will also commence the lesson of the tret by some exercises of the walk, with the changings of the hand.

You cannot attain the riding of a horse well, without repeating these exercises, and above all, that of the trot, until you are per- 
fectly familiarized with the different changings of the hand, also with the helps which you draw as much from this part as from the legs, and as you know how to adapt your attitudes and movements to those of the horse.

You will require a more free and lengthened trot, in proportion to the progress you will make, and you will pass to the following exercises when you will be sufficiently ad. vanced.

\section{Of the trot upon the circle.}

This lesson is extremely useful, to confirm a beginner in the two former lessons, and to learn him more and more to become master of all the movements of his horse.

After having gone through some tracks, and exercised some changings of hand, at first on the walk, then on the trot, upon a straight line, always, however, without stirrups or spurs, you will return him to a walk, and you will bring back the hand, without stopping, till you feel slightly the right rein, in order to bend the head, the neck, and the shoulders of the horse a little inwards, and the leg outwards; you will push him af- 
terwards on a trot, taking care to feel lightly the inside rein and outside leg.

The turnings and changings of hand will be executed in this lesson, in the same manner as in that of the gallop, of which we are going to speak; but you must pay attention not to allow the horse to lose his hold at the moment of bringing him up; the trot should be free, bold, and lengthened.

It is well to remark, that the lesson of the trot on the circle, fatigues beginners horribly, who take it without being prepared in advance by the trot on a right line. But nothing is more proper than this exercise, at once to supple the horse and the rider, and to increase his perpendicularity.

The lesson ought to finish, as it has commenced, that is, with the ordinary trot and walk.

\section{Of exercise on a gallop.}

This lesson, although less painful than the two preceding, is more difficult for beginners, and ought not to be taken before they are well instructed in the others.

After some evolutions and changings of 
hand on a walk, and on a trot, you will seize the moment you feel yourself in the best perpendicular position, to put your horse to a gallop.

It is essential for that purpose, that the rider renders the articulations of his reins, or lower part of the back and knees supple and soft, in order to preserve this perpendicularity, which would without it be infallibly lost.

It is also in this gait that the division of the three parts of the body of the rider is most apparent, because the part of the body called the waist, should be perfectly united to the movements of the horse, and the higher and lower parts, are in continual activity, to maintain the equilibrium of the entire mass.

To start on a gallop to the right, you must bring up softly the front of the horse with the bridle hand, at the same time that you force the haunches under him to go; throw down your hand, the nails upwards in order to stretch the left rein a little, which will force the horse to bend his head a little on this side, and render the shoulder more free, and consequently the right leg, which ought to start off first, this is what is called, to gallop on the right foot. You will at the $5 *$ 
same time make him feel the help of the legs, particularly of the right; as soon as he will have obeyed, you will make him lower his head a little inwards, by rounding the hand, the nails a little downwards, so that he may feel the right rein; you will hold the legs always near the body, to maintain the horse in action, and to continue the measured movement of the back part of the horse; this is what is called feeling the horse between your legs. The high part of the body should be held a little thrown back, and you must, from the moment you feel his quickness relax a little, yield your hand, and recover it back to its former position instantly, without changing the degree of the pressure of the legs.

When you will have arrived at the moment for tumning the corner to the left, you should, without deranging your hand, in order not to lose the bend of the horse, content yourself with bearing a little to the left, and the right leg will thus always be carried a little forwards. To depart from the corner, you let the hand fall on the right, which will hin. der the second raising of the front part of the horse; then the help of the legs, employed equally, will force him to go forward on the 
track of the last; the left leg on this side will be forced to whirl upon the heel, whilst the front part of the horse will bear upon the new track, that is to say, will start from the corner, to take the new line.

The different helps of the hand and of the legs should be in this action, proportioned to the quickness of the gallop, and combined in such a manner, that this quickness should not relax a single instant.

To change the hand in a gallop to the right, you will make the leg on this side felt. The horse being already bent, you will easily execute this evolution, but it will not be so when you will try to make him take the left track to gallop on this side.

The change of hand ought to begin with a time of stopping; in order to execute it well, you relax a little the right rein, and let the hand fall towards yourself, diminishing the pressure of the legs; by these means you will remove the bend of the horse, which will restore the shoulders. and the hips to a level. The horse having then recovered his perpendicularity, as he was on a walk, you will put him on his hips again; you will round your hand, the nails a little downwards, making 
him feel at the same time the help of the leg, for the purpose of making the left shoulder free, which will naturally carry forward the leg of the fore part on this side. When the horse will have obeyed, you will return the hand, the nails a little upwards, till the left rein is felt, in order to bring down the head inwards. The changings of the hand from left to right, and the taking the corners on a gallop on the left foot, are executed in the same manner, and by the same means, in an inverse sense, as the changings of the hand from right to left, and the taking of the corners on the galiop on the right foot.

When by the aid of these exercises repeated, you will have acquired the suppleness and freedom necessary for the part of the inferior extremities, you will begin to put on spurs, and to use stirrups.

The height which the stirrups will be carried, ought to be calculated by the manner in which they will carry the natural weight of the legs; when the stirrup straps are too long, they force the rider to stretch his legs beyond measure, to seek the stirrups, which would make him lose the perpendicularity which he should have on the saddle; when 
they are too short, they oblige him to let his knees fall, which would carry the heels too far in the rear, which would oppose the movements of all the lower parts.

You will repeat with spurs and stirrups, the lessons of walking, of trotting, of trotting on a circle, and on a gallop, always taking care to commence, and finish, each lesson, by some exercises of the precedent lessons. It is by these different exercises repeated with perseverance, and often, that you will attain the removal of the greatest faults, to which a beginner is subject.

When the scholar will be perfectly instructed in these first lessons, he should not certainly flatter himself with being a consummate horseman, but he will at least be in a state to manage a horse with grace and facility, and if he wishes to acquire a little more dexterity, he might pass to the following lesson.

Of the Shoulder inward, and of the Croup to the wall.

These two lessons are excellent to perfect the suppling of a young horse, when he will have been sufficiently exercised on the trot to 
teach him to go side ways, to pass his legs one over the other without hurting himself, to turn short without embarrassment or difficulty, and to give grace, etc. : they are not less necessary to a horseman under many other relations.

If he desires to train a young horse to the lesson of the epaule en dedans, when he will know how to trot freely with both hands on the circle, and on a straight line, with a tranquil and equal pace; when he will have accustomed him to make rests and half rests, and to carry his head inward, he must lead him to a little step slow and short, the length of the wall, and place him in a manner that his hips and his shoulders will be on two different lines.

The line of the hips should be near to the wall, and that of the shoulders a little more distant; the horse bent to the hand where you conduct him, that is to say, instead of holding him entirely straight on the hips and shoulders on the same line, you must turn his head and shoulders a little inward, as if you wished to turn him effectively, and without letting him quit this oblique and circular attitude, to make him go forwards along the 
wall, assisting him with the inward leg, and sustaining him lightly with the outside leg.

Now it is evident that he cannot go in this position without throwing the inside leg over the outside one.

M. de la Gueriniere, from whom I borrow the greatest part of this article, regards the lesson of the epaule en dedans, as the most advantageous of all those that can be employed to give a horse a perfect suppleness, and an entire freedom in all his parts. This is so true, says he, that a horse trained according to these principles, and spoiled afterwards by a bad horseman, passing afterwards into the hands of an able man, will be re-established very soon. The principal effects of this lesson, are to supple the shoulders, to put the horse upon his hips, and to dispose him to avoid the heels.

To execute the changings of the hand in the lesson of epaule en dedans, you must, without removing the bend of the head and of the neck, correct the shoulders and the hips, quit the wall, and make the horse go diagonally until he has reached the new track on which you wish him to go. There you must place his head to the left, if it was 
before on the right hand track, the shoulders inwards and detached from the wall, as before, and conduct him in this new direction until you judge it proper again to change the hand.

When the horse will commence to obey both hands, in the lessen of epaule en dedans, you will learn him how to take the corners well, which M. de la Guereniere again says, is the most difficult part of this lesson. You must for this purpose make the shoulders enter the corner without deranging the head, and in proportion as they go out from it, make the hips enter it in their turn, in order that they may pass every where through which the shoulders will have passed.

It is with the inside rein, and the leg of the same side, that you can push the horse forward in the angles, but when you turn him on the other line it must be with the outside rein, by carrying the hand inwards, whilst he has his leg raised and ready to fall, in order that by this movement the outside leg may pass over the inside one; you must at the same time prick him with the inside spur.

The lesson of the shoulder inside, or epaule en dedans, should be repeated until the horse takes the corners well, and executes all the 
changes of the hand freely, without difficulty, and without resisting. The trot, on an enlarged circle, is at once the best means of suppling, and, at the same time, of chastising horses, that resist through malice, the aforesaid lesson.

The lesson of the croup au mur, is naturally derived from the precedent; for, when the horse goes epaule en dedans to the right or to the left, he is at the same time disposed to avoid the heels on the hand of the opposite side. Thus, for the purpose of giving this lesson, after having placed the horse on the right track, you will at first put him to the gait of epaule en dedans, then you will turn him, la croup au mur, or the croup to the wall, in such a manner that the shoulders and the hips may be placed in a line right across the track.

In this posture you will excite the horse easily to make some steps aside, by supporting the right rein, and lightly the leg of the same side. If the horse does with docility some steps, throwing the right leg well over the left, you will stop him to caress him, to make him comprehend that you are satisfied with him; then you will recommence and 
stop him again at the end of some steps, and thus in order, to the end of the track. After having let him repose there an instant, you will feel the rein, and the left leg, in order to change hand, and you will bring him back in this manner, always on the side to the point from which he had gone.

As this lesson will fatigue and embarrass the horse, at the commencement, if he be not yet trained, you will conduct him at first slowly, stopping him frequently to caress him when he will have obeyed, and avoiding to discourage him when he does not obey.

If, going well on one hand, he obstinately refuses to go, la croupe au mur to the opposite hand, it will be a sign that the shoulder on this side is not sufficiently supple, and you should return him to the lesson of epaule en dedans.

M. de la Gueriniere thinks, that the lesson de l'epaule en dedans and that of the croup au mur which ought to be inseparable, are excellent to give suppleness to a horse, a beautiful bend, and beautiful posture, which he ought to have to move with grace and lightness; it is not necessary for that purpose to abandon the lesson of the trot on a right 
line, and on circles; you must always return to these first principles to preserve him and confirm him in a bold and sustained action of the shoulders and the hips. By this means you divert the attention of the horse, and relieve him from the subjection in which you are obliged to hold him, during the lesson of the croup au mur, and de l'epaule en dedans.

This author wishes that of the first short lessons that you will make every day, the first may commence by the lesson of epaule en dedans on a walk; and after two changes of the hand on the same track, you will put the croup to the wall with two hands, and you will finish on a walk by a track on a right line; the second lesson after a rest should be devoted to a bold and sustained trot : the third and last will be like the first. By combining thus, these three lessons, of epaule en dedans, of trot, and of croupe au mur, you will see if I may so speak, the suppleness and obedience of the horse, as well as the address of the rider, increase. 


\section{Of stops, half stops, of falling back, and of the changes of hand.}

This lesson is necessary to a beginner, to teach him in every sense more and more how to govern his horse: it is not less useful to place a young horse on his hips, and to render him light to the hand. If a horse in moving uses his shoulders and his hips equally, he would seek in the bridle a proper rest to counterbalance the natural weakness of his forepart, and he would bear too much on the hand.

You may accomplish the prevention of this fault, which very much injures the confidence of the horse, and extremely fatigues the rider, and give the horse a light mouth by habituating him to advance his hind feet and houghs under the belly in moving, and to take his principal point of rest in the hips: this is what they call putting a horse on his hips. Nothing is more proper for that purpose, than the practice of stops, half stops, and falling back.

'The arret, or stop, consists in drawing back with the left hand the head of the horse, and 
the other foreparts, by pressing forward, delicately, at the same time the hips with the calves of the leg, so that all the body of the horse may rest in equilibrium upon the back feet; a movement much more difficult to be executed by the horse than that of turning, which is more natural.

To make a stop well, you must take the moment the horse is very animated, and make him delicately feel the help of the legs, at the same time that you will put your shoulders a little backwards, and make the bridle more and more firm, until the horse be entirely stopped. You must, whilst you execute this movement, close your elbows a little towards the body, in order to have more security in the bridle hand; it is necessary that the horse be straight in order that the hips be equal, without which the stop would be false. The stop in a trot should be made at once; the back feet straight, and not advancing one more than the other, but in the gallop, the movement of which is more extended than that of the trot, you must stop the horse, two or three times, in proportion as the front feet fall on the ground, in order that when he lifts himself up, he may be on his hips. For 
that purpose, in drawing back the hand, you must aid him a little with the back of the knees or calves of the legs, to make him slip his hips under him. It is good to accustom a horse that you are training, to make stops as soon as he becomes light to the trot, and turns easily to both hands, but at first it must be done rarely, and with great precaution, for by stopping a young horse, or one weak in the reins, suddenly, you would risk forcing these parts, as well as the back part of the knees, and ruining the animal forever. The rider ought also to take care that the high part of his body does not make a movement in front, at the moment in which the horse stops, an inconvenience he will prevent by strengthening beforehand his reins. Every time that you stop your horse, you must not forget to caress and soothe him.

The advantages of a well made stop, are to collect the powers of a horse, to make the mouth, the head and hips sure, and to render him light to the hand, but in the proportion as these means are efficacious, when employed judiciously, so are they injurious if they are employed improperly. To resume the time of stopping, making the whole effort 
pass in the reins and the houghs, extremely fatigues these parts of horses that are naturally feeble, and soon ruins them.

There are but few horses that are sufficiently vigorous to support this action frequently repeated. The greatest proof that a horse can give of his powers and of his obedience, is to make, after a rapid course, a firm and light stop: which evidently denotes an excellent mouth and excellent hips, qualities as precious as they are rare.

The half stop consists in drawing the bridle hand lightly towards you, the nails a little upwards, without immediately stopping the horse, but only drawing him back, and raising up the forepart, when he rests on the bit, where you wish to bring him back, or to gather him up. This action produces nearly the same effects as the full stop, without discouraging or fatiguing the horse as much; and for this reason you ought to repeat it in preference and employ it frequently, above all with horses that have a bad habit of resting too much on the hand. As to those that are naturally disposed to retain themselves, you must at the same time that you make them mark a half stop, animate them with the 
calves, and even sometimes with the spurs, for fear that they do not fully stop.

To make a horse fall back, the action of the bridle hand is the same as to mark a stop; so that to accustom a horse to fall back easily, you must, after having made the stop, draw back the bridle, the nails upwards, as if you wished to make a second stop; when the horse will have obeyed, that is, when he will have made two or three steps backwards, you must yield your hands to soothe his lower jaws, otherwise a too long pressure on the part of the bit would stupify him, and the horse, instead of falling back, would force the hand, or make a full stop.

To fall back well, you must, at each stop that the horse makes in the rear, hold him ready to advance anew; it is a great defect to fall back too quickly, because the horse precipitating his force backwards, runs the risk of throwing himself on his tail, or of throwing himself on his back, particularly if he has weak reins. It is necessary also that he fall back straight, without crossing, in order to bend the two hips equally under him ; if he is obstinate and does not wish to fall back, which often happens, almost generally 
with horses which have not been well trained, it is necessary that a man on foot give him some small touches with the whip on the knees and ancles; at the same time the rider should draw the bridle to him, but if he does not obey, you must caress him at each sign of obedience that you obtain from him.

When a horse falls back, he has always one hind leg under the belly, he pushes the croup behind, and he is at each movement sometimes on one hip, sometimes on the other, but he cannot well execute this action, and it ought not to be required of him, until he begins to become supple and to obey the stop, because you are better able to draw his shoulders to you when they are free and sup. ple, than when they are stiff and benumbed. This lesson, always occasioning an effort more or less painful to the reins and houghs, should be used moderately at the beginning, particularly with horses that have these parts naturally weak. It becomes, for the same reason, a chastisement for horses that do not well obey the stop, but on the other side it is a good way to put a horse on his hips, to make him adjust his back feet, to steady the head, and to render him light in hand. 
The action of changing the track in moving, or of placing the horse on another foot, is called changing the hand. To execute these changes well, you must round your hand a little, and carry it on the side you wish to go, assisting the horse at the same time on that side, and sustaining him lightly with the other; all this should be done with precision, without shaking, and without retarding the gait of the horse. Many persons, are in the custom of alternately passing the reins and the whip from one hand to the other at each change, but this practice is not necessary, above all to beginners, as it would serve but to increase the embarrassment that they generally experience when it is necessary for them to change the hand.

It is by the assistance of these changes frequently repeated, as well as stops and half stops, that a rider will easily attain the possession of a good hand, that he will accustom a new horse to go with both hands, and execute without difficulty or embarrassment, all the evolutions that he will desire.

The narrow limits of this manuel will permit me to give but a circumscribed extent to each of its parts. I believe I must terminate 
here, what I have to say on equitation. The small number of lessons which form the matter of this last chapter, seem to me sufficient to put every man who will not have the pretension of becoming a consummate horseman, in a state of being his own master.

As to persons who desire to acquire more profound knowledge, they will not be able to obtain it from the most cornplete treatises, if they do not at the same time join to them the practical lessons of Franconi, Pitou, or other great masters. 



\section{APPENDIX.}

$\rightarrow \gg 094$

\section{DIRECTIONS FOR THE IADIFS.}

OF MOUNTING.

Preliminary.

THE pupil should be brought forward by degrees, and with due preparation. Her lessons should be short and gentle, as well with a view to her gradual progress, as to prevent injury from too great exertion.

Some teachers so much regard this progression, that before they place a lady on horseback, they make her execute, and that with facility, lessons with the bridle and saddle alone; and these occupy her attention several days.

The early lessons are given with a snaffle bridle, on a well trained and steady horse.

The first instructions are those of mounting and dismounting. 


\section{Of Mounting.}

Whatever the disposition of a horse may be, he should be approached apparently in good temper. Horses know by appearance whether the rider is angry or pleased, bold or timid, handy or awkward. A soothing tone of voice and caresses are pleasing; and to such as are unsteady, or have a dislike to be mounted, it helps to dispel their fears. Young horses especiaily should therefore be thus gently treated, and much encouraged.

Before mounting, it is proper to observe whether the saddle is rightly placed, the girths secure and not too tight (for many horses are apt to plunge when they are), the bridle fitly on, and the curb, when used, smoothly placed.

Let the assistant adjust the reins of the bit smoothly, and of equal length, taking it up within the bridon rein, and dividing the reins with the forefinger of his left hand.

The lady receives the reins from him with her right hand, just before the pommel of the saddle, the whip being in it, which passes over to the off side. 
The lady puts her forefinger between the reins, gently letting them slip, not to disturb the horse, till her hand rests and lays hold on the near crutch or ponmel of the saddle.

She stands then close to the horse, upright, with the face half turned from the saddle. The assistant places himself before her, and, where practice has been wanting to make either expert at this business, it will be best for the assistant to place both his hands together by the intersection of his fingers. He then stoops to receive the lady's left foot, which must be placed full and firm on his hands.

The lady then places her left hand on his right shoulder, by which, and the hold she has on the pommel of the saddle, she steadies herself, while she bears all her weight on the assistant's hands, straightening the left knee and keeping it firm.

Should the lady be heavy or inactive, the more particular care is requisite in both :on the lady's part, that she bear her weight centrically and perpendicularly in the hands, not putting her foot forward as she raises it, by which she would shove the person from her : on the assistant's, that he place himself 
in such manner that the lady may be between him and the saddle, his face directed so that he can stoop to assist the lady without removing himself to a distance; for the closer he stands, the greater his power to assist.

The assistant must not attempt to raise the lady till the right foot has quitted the ground, and the left knee is nearly straight : otherwise he will prevent the lady from raising herself in his hand.

The assistant now, by raising himself, raises the lady to the saddle, where she pauses while the assistant places the stirrup on her left foot.

'This done, the lady shifts her right hand from the near crutch of the pommel, to the off crutch of the pommel ; and the assistant places his right hand under the lady's left arm, by the support of which, and the hold she has with her right hand, she will raise herself upright in the stirrup.

The assistant with his left hand draws the clothes next the saddle forward.

This being done, the lady places her right knee over the pommel of the saddle, and then seats herself.

By this mode, if properly attended to, you 
will find several inconveniences avoided, such as the binding of the clothes under the right knee, the difficulty of raising the knee over the high pommels now in use, \&c.

Should the clothes want any adjustment behind, the lady with her left hand takes hold of the assistant's left hand, her right hand having hold of the pommel, and raising herself forward, the assistant at the instant, with his right hand, adjusts them smoothly.

When ladies become expert horsewomen, they can adjust their clothes when they become uncomfortable, without assistance, and consequently are not necessitated to have their clothes pinned. This they can do when riding at any pace, or standing still, at their pleasure.

The method of doing it is to take the reins in the right hand as directed when mounting, holding by the off crutch or pommel of the saddle, and raising yourself up. The action of the horse, if moving, will then considerably assist you. With your left hand, each time you rise, pull and shake your clothes down, and endeavour to raise yourself as high as you can for that purpose.

When the clothes rise before, it may be 
necessary to remove the knee from the poinmel. This few ladies choose to do, nor is it adviseable, but when the horse stands still, or is only in a slow walk. You then, having hold as before, and leaning the body back, but raising yourself upright in the stirrup is best, remove your knee, and thus standing, let the garments fall down by a momentary shifting of any part that presses them to the saddle; which done, place your knee again, and seat yourself.

Pouches in the skirts of the habit, with leads in them, are very convenient; the habit then flows more gracefully than when pinned, and the petticoats may be pinned under the skirt, if the lady prefer it.

Ladies who ride should have their hair very firmly and closely dressed, and their hats pinned, so as to prevent their being moved by the motion of the wind, or the horse, or the brims flapping over their eyes; for either of these not only greatly embarrasses the rider, but prevents her seeing how to guide her horse.

\section{Of disposing the reins.}

The pupil should then divide the reins 
holding them separated with the little finger of each hand, the end of the reins being thrown over the fore-fingers, the thumb closed on them, and the finger shut.

When afterwards further advanced, she holds the reins in the left hand.

\section{OF DISMOUNTING.}

Ladies dismount their horses with, and occasionally without, assistance.

In either case, they first shift the reins to the right hand, and apply it to the off crutch of the saddle.

The gentleman officiates, if present, in clearing the lady's clothes from the pommel of the saddle, as the lady raises her knee over.

Taking the stirrup from the foot, the lady then shifts her right hand to the near crutch of the pommel.

In whatever manner the lady may choose to dismount, it is necessary to be careful that the clothes are off the pommel of the saddle, and the stirrup free of any entanglement.

I. If the lady is alert and active, she may dismount very gracefully, by giving her left hand into the gentleman's left hand; and, springing just sufficiently to clear the saddle, she will alight on the balls of the feet, with 
the knees a little bent, so as to drop a small curtsy, which will prevent any jar which might otherwise take place.

The gentleman must have his right hand ready to apply under the lady's left arm as she alights. Thus he may not only lighten her down, but prevent any accident that might occur by the lady's foot alighting on anything that might occasion her to slip.

II. Should the lady not choose to spring in this manner from the horse, she will lean forward, and the gentleman will receive her with a hand under each arm, and lighten her to the ground.

III. When the lady dismounts without helf, after clearing her stirrup, and every thing as above described, she turns herself to the right in such manner that she may lay hold, with her left hand, of a large lock of the horse's mane, keeping hold at the same time of the near side pommel.

She then springs from the horse to clear her clothes.

She alights on the balls of her feet, with her knees a little bent, for the purpose before directed, and her face to the horse's withers, keeping fast hold with both hands till she is firm and secure on her feet. 
TOCA B U JAR

OF TERMS OF

\section{THE FRENCH MANÉGE,}

TH F

Explanation of which is not found in this Manual.

Abandonner son cheval. To let the horse go with all his speed, without restraining him with the bridle, and not sustaining him sufficiently.

Acculer. It is said that a horse s'accule, when he falls back in going sideways, and when his hips move before his shoulders.

Acheminer un cheval. To supple and instruct a horse, to prepare him to any air of the manege. It is said of a horse that shows good dispositions, and good will, and that understands the bridle well, and answers easily to the helps, that he is well instructed. Aids. See the first chapter for their definitions. It is said of a rider that he has fine helps, when he assists his horse with grace, $8^{*}$ 
ease, and by almost imperceptible movements. The same thing is said of a horse prompt to obey the helps.

Air,-Is said of the fine attitude of a horse in the various evolutions that he executes, and of the cadence that he observes in his movements, according to the species of gait, whether natural or artificial, in which he moves. Certain artificial airs or gaits invented to display at once the grace and suppleness of the horse, and the address of the rider. Airs are called low or lofty according as they are more or less detached from the ground.

Allures, or gaits. See in the first part the article devoted to the gaits of a horse.

Appui, or rest. The sensation which the bridle produces in the hand of the rider, and reciprocally the action that the hand exercises on the lower jaw of the horse by means of the bit. A horse has no rest when he cannot support the action of the bit, and when he gives blows of the head for the purpose of relieving himself from it; he has too great a rest when he presses heavily on the bridle; he has a liberal or free rest, when, without pressing or beating the hand, he leaves in the 
hand of the rider the feeling of a soft and equal pressure, which is the effect of an excellent mouth. The same thing is said of the hand of the rider with regard to the effect that it produces on the mouth of the horse.

Appuyer les eperons, or to rest the spurs. To make them vigorously felt.

Armer, or to defend himself. Is said of a horse that defends himself against the action of the bit. See the article on the choice of a bit in the first chapter.

To sit a horse upon his hips. To render him firm on this part, for the purpose of easing the fore part of the horse. It is also said of the rider, that he sits on the saddle, or in the saddle, that is to say, renders him. self firm on the saddle bows.

Assiette, or seat. Attitude of the rider on the saddle. It is said, to lose the seat,-to have a good seat.

Attaquer, to attack. To make the horse feel the spurs or the chambriere.

Avertir au cheval, to uarn a horse. To make him feel the helps, to reanimate him, or to indicate to him what you wish him to do.

Balancer, to balance. Is said of a horse that throws the croup right and left when moving. 
Ballotade. Air of the manége. It is a high leap, in which the horse, having his feet in the air at an equal height, presents the shoes of his back feet as if he wished to kick, without in the mean while slackening the kicking. See Capriole.

Battre al la main, to beat the hand. See Hand.

Brouiller au cheval. Is said of a rider who, not knowing how to harmonize the movements of the hand with those of the legs, confuses his horse, that he does not know which help to obey.

Cadence. Regular and heard measure that the horse observes in his movements. It is said of a horse that he sustains, or does not sustain, his cadence; that he loses or preserves his cadence.

Capriole. Air of the manége. It is a leap analogous to the ballotade, with this difference, that the horse being in the air, slackens the throw, with the quickness of lightning, and with all his force.

To confirm a horse in the air of a manége, a gait, a lesson. It is to continue him in it until he is perfectly trained.

Courbette. Air of the manége in which 
the horse raises the forepart in bending his legs downwards, and bends his haunches under him.

Croupade. Another air of the manége, more lofty than the courbette, and in which the horse, being in the air, draws up his hind feet under his belly almost at the same height as those in front.

Dedans, inside. The side on which a horse is exercised. Thus when he works on the left, or on the right hand, all the part of this side is called the inside, the opposite part is called the outside, it is evident that in the manége, the part of the horse which is next the wall or barrier is that which is called le de hors, or, the outside.

Defendre, to defend. It is said of a horse that he defends himself, instead of obeying the aids or helps, when he seeks to free himself from their subjection by all the means in his power.

Derober, or to slip away. When the horse in galloping, redoubles his speed, seeking to pass from between the legs of his rider, it is said that he seeks to slip from under his rider. 
Doubler, to double. To turn a horse without changing of hand.

Ecouter son cheval, to hear one's horse. To be attentive not to derange him from his gait when he goes well; to hear his movements.

Estrapade. A leap in which the horse raises the croup higher than the forepart by drawing up his hind feet with violence, for the purpose of throwing his rider over his head: this is a very dangerous leap for the rider.

Hand. This term is employed in the manége in a multitude of circumstances: as well where it refers to the feet of the horse as to the hand of the rider. It is thus that we speak of exercising a horse on the right hand, or on the left hand, according as he is put on the one or the other foot. To work from one hand to the other, to turn the horse on a track, with the aid of one hand, without employing the legs. To yield or draw back the hand, is to lower the left hand for the purpose of decreasing the action of the bit, or to execute the contrary. It is said of a rider who has a rough hand, and holds the bridle too firm, he ties himself to his hand; 
of a horse who by ignorance or disobedience draws the bridle in raising the nose in front, that he draws the hand; of him who rests upon the bit as upon a fifth leg, that he is heavy in the hand; of him who gives blows with the head, as if to shake off the bridle, that he beats the hand, a very ordinary defect among horses that have the hand badly placed, or the lower jaws too sharp. To be in the hands, and in the heels, is said of a horse perfectly trained, who obeys in all circumstances with an equal facility the helps of the hands and legs; it is the beau ideal of the perfection of a horse.

IIanége. This word is designed at once to express the various exercises of the school in which horses are taught, and the place in which they are trained to these exercises. It is said, in the first acceptation, that a horse is well or badly trained at such or such a manége: there are manéges for war and manéges for schools. The manége in which horses are exercised, is a space of one hundred and fifty feet long, by fifty wide, more or less, and chosen in a firm soil, level and flat: some are enclosed and covered, and some are not. 
Montoir, or side to mount. The left side of the horse is called the mounting side, and the other side the off side.

Mouton. The sheep leap differs from the strapade in this, that the horse does not kick in the former which renders it less dangerous for the rider.

Passades. To make passades. It is to conduct a horse in a right line, in changing at both ends from the right to the left, and from the left to the right, to return to the point of departure, passing and repassing always on the same line.

Pesade. Air of the menége, in which the horse is trained and holds himself firm on his hind feet, as if he wished to leap, but without moving from his place.

Piaffer, to Piaff. Is said of a horse that moves his legs in cadence, as if he was going, but without advancing from his place, and in holding himself wcll in the hand, and the legs of his rider. Piafing gives much grace in a horse well trained.

Pirouette. An evolution in which the horse turns on himself from head to tail, without changing place, the hind leg of the inside, 
doing in this case the office of a pivot, on which the rest of the mass turns.

Piste. This word serves to designate the plan that a horse follows in moving. He goes on one track when he goes straight, that is to say, when his shoulders are on the same line with his hips, and when his hind feet follow those of the front; he goes on two pistes or tracks, when the shoulders do not follow the line of the shoulders, as when he goes sideways.

Forter, to carry. Is said of the manner a horse carries his chest when moving; to carry high, to carry low. This word signifies also to make a horse go, to carry a horse in front to the right, and to the left, and sideways.

Racourcir un cheval. To slacken his gait, by drawing back the bridle.

Ramener. Is to make a horse lower his nose, who carries it in the wind, and draws the hand.

Rassembler. Is to draw up a horse and put him on his haunches, and to prepare him to obey the helps; which is done by drawing up the front with the bridle hand, at the same time that you force forward the haunches under him. 
Reprise, is said of a lesson that is repeated after having allowed the horse to repose, or otherwise, the duration of each exercise that he is made to do.

Ruade. An impetuous movement in which the horse lowering his head, and raising his back, suddenly throws, with all the force of which he is susceptible, his hind legs, and shows his heels.

Saccade. Is said of a violent shake that the rider gives to the mouth of his horse, by drawing the bridle roughly.

Sustenus, sustained. Is said of movements, lofty, heard, cadenced, and very regular.

Terre a terre. A sort of gallop, lively and low, which is made on two tracks.

Traverser. Is said of a horse, who, instead of going straight, when you wish to put him on a track, throws himself, sometimes on one heel, sometimes on another, and moves slantingly.

Trepeigner, to beat the ground with the foot. Is said of a horse, who, being at rest, strikes the ground with the foot through impatience, or excess of ardor.

Tride, lively. An adjective employed to designate precipitate movements, in which a 
horse lowers his hips under him, promptly and lively. It is said that a horse has la course tride, when he gallops with his hips short and quick.

Volte, fight. An air of the menége, in which a horse going on two tracks describes two parallel circles. 


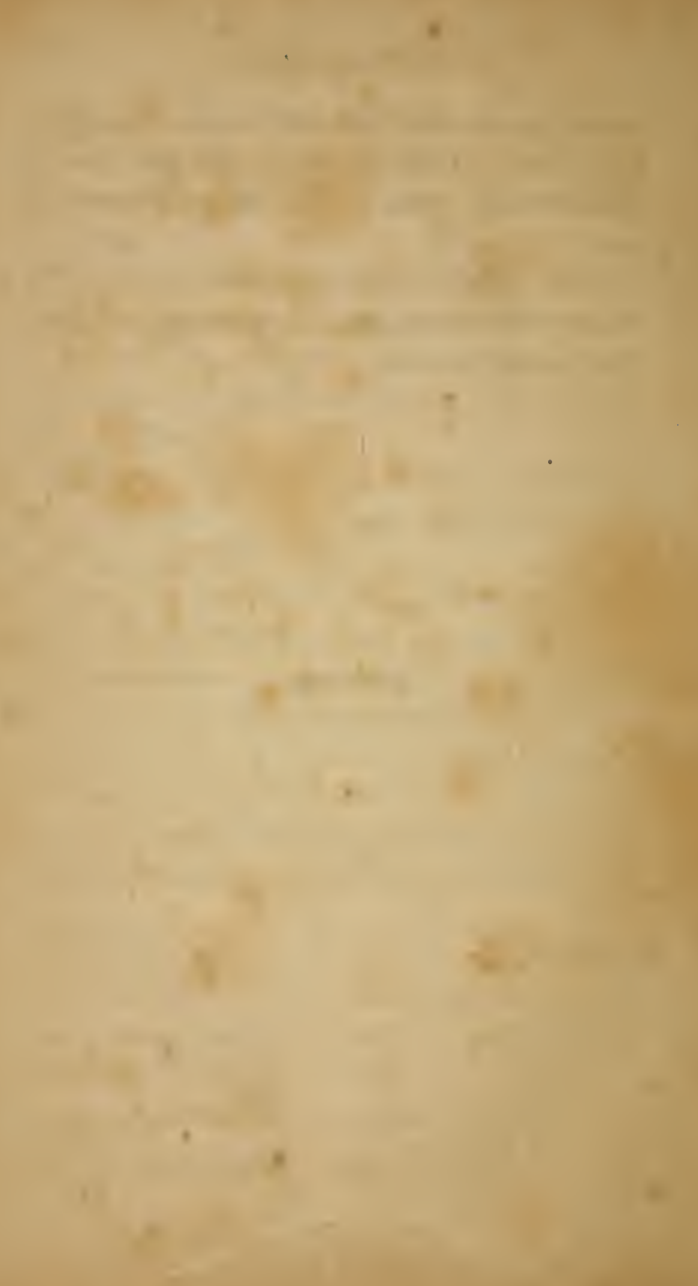




\section{NEW WORKS,}

IN PRESS BY

\section{E. L. CAREY \& A. HART,}

Corner of Fourth and Chesnut Streets.

$\rightarrow \gg$ Peस

1. CONTRAST, a novel, by Earl Mulgrave, author of Matilda, and $Y$ es and No, in 2 vols. (nearly ready.)

2. A SUBALTERN IN AMERICA, during the late war, 1 vol. $12 \mathrm{mo}$.

3. TRAITS AND STORIES OF THE IRISH PEASANTRY, 1st. series, 2 vols. $12 \mathrm{mo}$.

4. THE STAFF OFFICER, or Soldier of Fortune, 2 vols.

5. A MANUAL OF HORSEMANSHIP, translated from the French, 1 vol. $18 \mathrm{mo}$.

6. TOM CRINGLE'S LOG, 2 d series, 2 vols. $12 \mathrm{mo}$.

7. THE MAN-OF-WARS-MAN, by the author of "Tom Cringle's Log," 2 vols. 12 mo. (nearly ready.)

8. MEMOIRS OF MARSHAL NEY, compiled from papers in possession of his family, 1 vol. $8 \mathrm{vo}$.

9. BLAKE'S CONVERSATION ON BOTANY, 1 vol. $12 \mathrm{mo}$. colored plates.

10. WOMAN THE ANGEL OF LIFE, a poem, by Robert Montgomery.

11. PETER SIMPLE, or Adventures of a Midshipman, 2 vols. $12 \mathrm{mo}$.

12. THE INVISIBLE GENTLEMAN, by the author of "Chartley the Fatalist," and "The Robbers," 2 vols. $12 \mathrm{mo}$.

13. FROISSART AND HIS TIMES, by the late Barry St. Leger.

14. THE WAY OF THE WORLD, by the author of De Lisle, 2 vols. $12 \mathrm{mo}$.

15. THE NAVAL OFFICER, 2 vols. $12 \mathrm{mo}$.

16. MOTHERS AND DAUGHTERS, a novel, by the author of Pin Money.

17. TOM CRINGLE'S LOG, a new edition, complete, 3 vols. $12 \mathrm{mo}$.

18. FIVE NIGHTS OF ST. ALBANS, a novel, in 2 vols. $12 \mathrm{mo}$. 


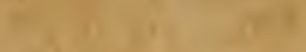

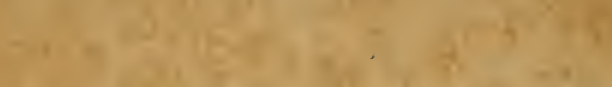

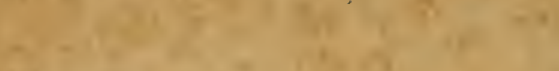

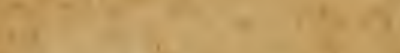

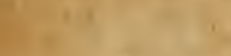

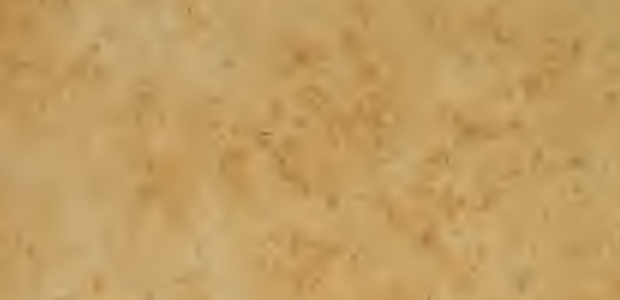

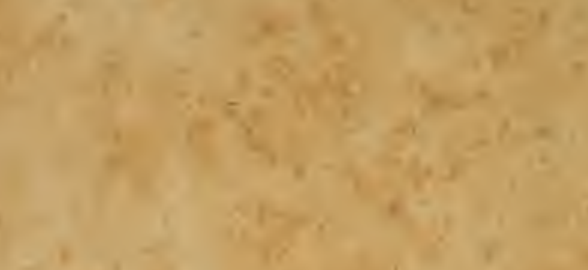

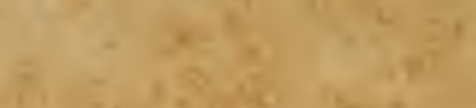

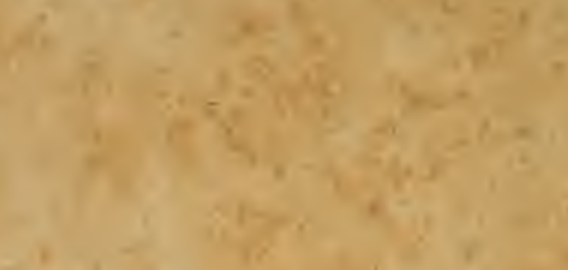

1

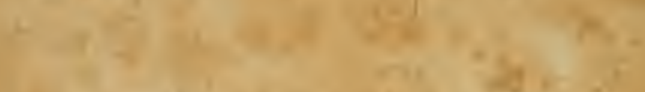

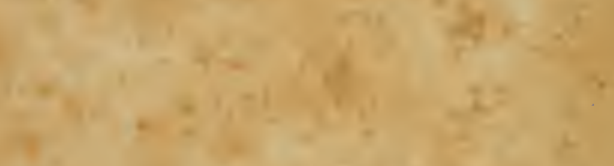

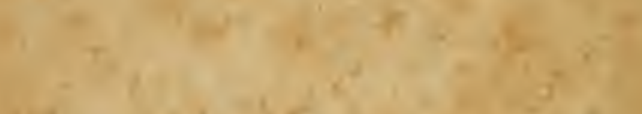

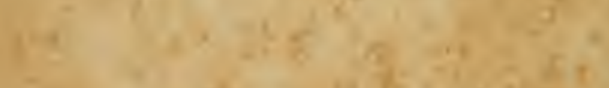

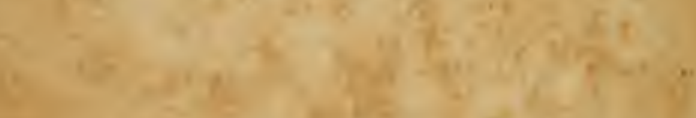

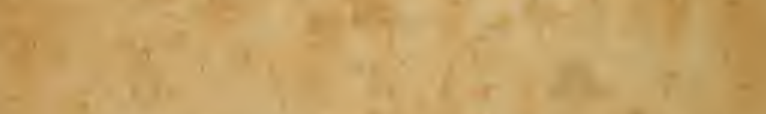

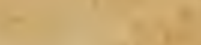

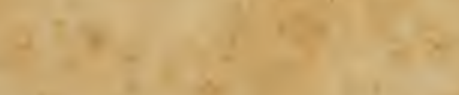

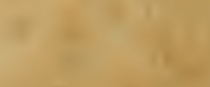

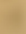

$$
\text { asis }
$$


$+\frac{1}{4}$

1

I

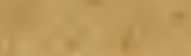

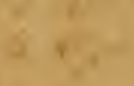<smiles>C1CCCCC1</smiles>

$1-2+2+2$

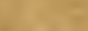

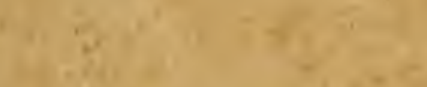

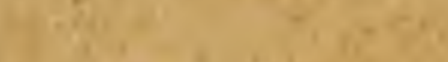

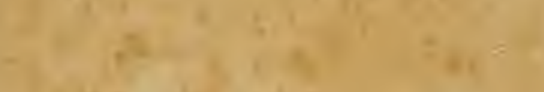

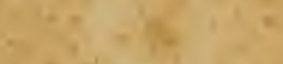

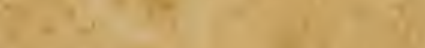

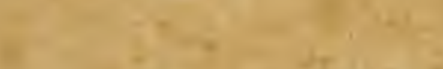

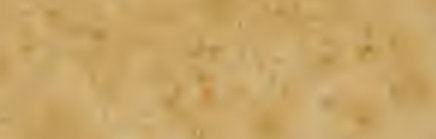

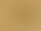

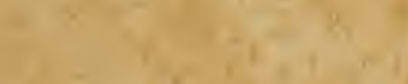

$12 y^{2}+1,2$.

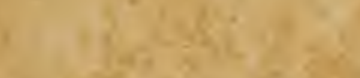

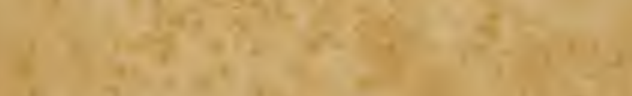

$x^{2+2}+$

in $+2$

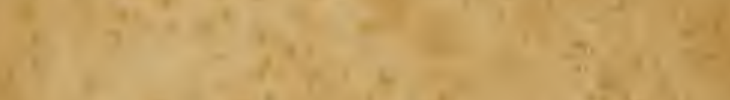

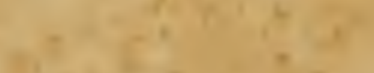

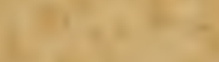

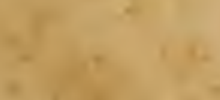<smiles>C=C1CC1</smiles>

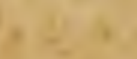

\section{$\sin +2$}

$+2$

$2+1-18,4=$

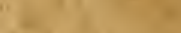

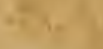

\section{tat

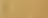

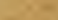

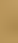

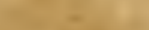

$\sqrt{2}+2$

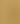

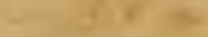

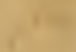

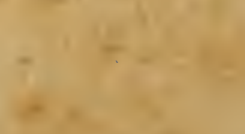




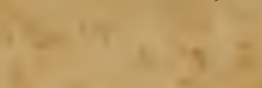

$+$.

$+9$

x.

1,1

II

I

$1=1$.

6. $3 x=10$

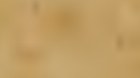

$+\infty$

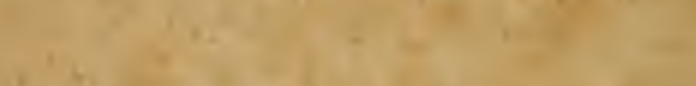

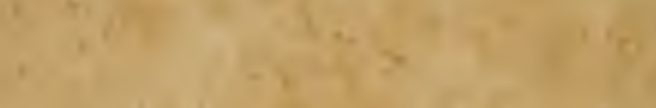

7

$$
+1+1+i=
$$

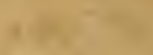

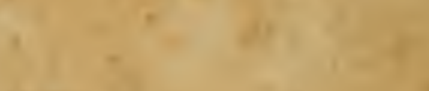

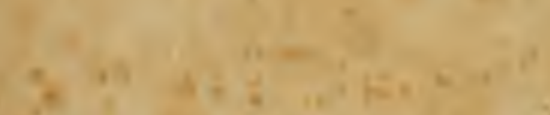

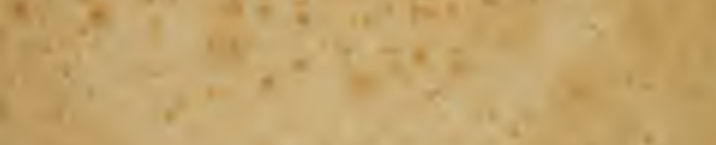

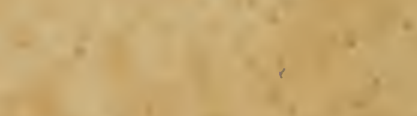

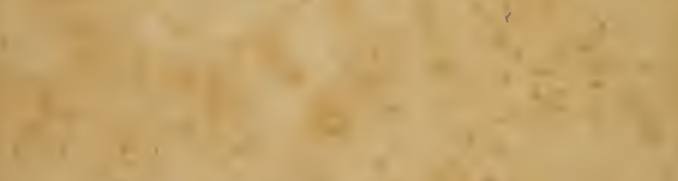

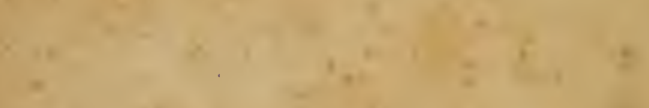

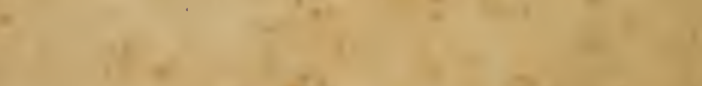


? 